\title{
The Case Against (Actually Existing) Higher Education: Human Capital, Educational Signalling, and Justice
}

\author{
Christopher Martin (University of British Columbia)
}

Most everyone understands that the worldwide expansion of higher education (HE) is driven by the "college wage premium": the boost in income that a person can expect on graduation. "Getting a better job" continues to be among the most important reasons United States (US) students seek a higher education (Morton, 2016; Egan et al., 2017). But economic motives often jar with the sensibilities of teachers and scholars. They are trained to value knowledge for its own sake. They believe in education as a force for positive transformation. Their worldly success is tied to the pursuit of unworldly ideas. Many of them are unlikely to see employability as the central aim of their teaching.

Nevertheless, the orthodox explanation of the college premium provides something of a consolation. According to human capital theory, the reason why the college premium exists is because of a strong demand for skilled labour, and a higher education provides the very skills those employers are looking for. ${ }^{2}$ On this view, while the promise of a better job leads students to the graduation platform, the system imparts real knowledge and skills along the way. Even more, this knowledge and skill contributes to the health, wealth, and productivity of society at large. This, in turn, justifies public subsidies for higher education systems.

The economist Bryan Caplan, however, has sought to resurrect a competing theory. His book, The Case Against Education (2018), makes a detailed empirical argument for the signalling model of education's incomeboosting power (p. 13-19). Key to understanding the signalling model is the information asymmetry that employers face. They want workers with a good work ethic. They want workers with intelligence. They also want workers that are willing, and able to, conform to workplace values and norms. The problem is that it can be quite hard to know if an employee has these attributes until after they have been hired. A job applicant can talk a good game, after all. Employers are therefore on the lookout for reliable information - signals - that on average indicate worker productivity. And education, argues Caplan, has become the dominant signal.

Signalling aims to explain why employers pay more for graduates even when they have completed degree programs wildly disconnected from the work that they come to actually do. The longer you can thrive in a system of formal education, the signalling model states, the more likely it is that you possess the traits-sufficient intelligence, motivation, and conformity-to be a productive worker. Buck the trend and turn away from formal education and you're signalling non-conformity and are less likely to be productive from a statistical point of view.

Signalling also aims to explain credential inflation. On a human capital view, the demand for education credentials scales with the increase in the complexity of skill-based labour. But we can think of many examples, such as the undergraduate degree as a requirement for entry-level work, where credential creep has outpaced the human capital explanation. According to signalling, as more workers flock to a signal that pays (like the undergraduate degree) they need to look for an even stronger signal (the master's degree) in order to stand out from the crowd (Caplan, 2018, p. 102-108).

In short, the signalling model says that employers do not pay more for graduates because of the great job that educators are doing at imparting new knowledge and skills. Rather, academic completion - persisting in the systemprovides credible and reliable information to employers about a worker's basic dispositions and skills. Importantly, these dispositions and skills pre-exist the educational process (Caplan, 2018, p. 13). As economist Kenneth Arrow (1973) put it in an earlier formulation:

Higher education, in this model, contributes in no way to superior economic performance; it increases neither cognition nor socialization. Instead, higher education serves as a screening device, in that it sorts out individuals of differing abilities, thereby conveying information to the purchasers of labor. (p. 194)

Of course, empirical theories are often blunt instruments for understanding social phenomena. The signalling model states that higher education contributes nothing to human capital, but the real question is how much of higher education is signalling. Caplan's approach is to take a hard, data-driven look at the various ways in which education contributes to both private and social returns. His claim is that a lot of the returns we think are caused by 
teaching and learning can be attributed to other factors. One major factor, he thinks, is ability bias. Apparently, when you hold educational attainment as a constant, higher intelligence correlates with higher income (Caplan, 2018, p. 73). However, the education wage premium is still strong even after correcting for ability bias. Some declare this a win for human capital, but Caplan argues that most of the remaining "effect" can be attributed to educational signalling. Consequently, Caplan concludes, we vastly overestimate education's real returns.

How much of the educational wage premium does Caplan think can really be attributed to education? He puts this measure at about $20 \%$. This means that a staggering $80 \%$ of education is merely signalling - a costly broadcasting of worker potential that contributes nothing to the productivity and wealth of society. ${ }^{3}$ When states "invest" in education, what they are mostly doing is fuelling a voracious appetite for costlier (and time consuming) education signals. Caplan therefore argues that the state should a) make radical cuts to the curriculum (by removing "useless courses" that do not inculcate labourrelevant skills) and b) make radical cuts to the funding of compulsory and higher education.

\section{Educational Justice and the Case Against Higher Education}

What to make of Caplan's economic claims, and the policy recommendations he believes to be consequent from them? I leave it to the economists to score points for and against the data. But it seems to me that he has marshalled enough evidence to support educational signalling as a real phenomenon, especially for higher education. While there is some evidence that compulsory schooling imparts private and social returns, the returns of higher education are dismal by comparison (Caplan 2018, p. 185). Where I diverge from Caplan is on what, given his analysis, we ought to do about it.

I begin with two general observations that outline terms on which I agree with Caplan, given his analysis, and where I think that scholars interested in questions of educational justice and fairness in higher education should pay particular attention. In the final section, however, I argue that Caplan's defense of "radical" cuts as the only way forward elides important questions about the justification of higher education.

\section{Higher Education as an Engine of Inequality}

While Caplan (2018) concedes that radical cuts to education align with his own libertarian tastes, he thinks that those committed to social justice should be worried about signalling, too. For example, note that for egalitarians the state ought to reallocate public resources within higher education systems in order to mitigate the unfair advantages that many wealthy and middle-class students experience in terms of their access to, and completion of, a higher education (Bou-Habib, 2010). Means-tested, low-interest student loans would be one example of an egalitarian intervention (Brighouse, 2004). This makes intuitive sense and is the right move if a higher education significantly increases graduate productivity. In such a world, barriers to higher education undermine equality of opportunity ${ }^{4}$ by making it harder to "learn and earn" simply because one happens to be poor. This is an unambiguously unjust scenario.

But if Caplan is right, signalling means that redistribution won't improve equality of opportunity in the long run. It just fuels the educational arms race. Dumping more resources into the higher education system in order to widen access and completion rates for the poor actually makes society more unequal from an all-things-considered point of view. This is for two reasons. First, as educational credentials become more accessible to the poor, richer citizens have sought out more exclusive credentials in order to send a stronger educational signal to the labour market. Credential inflation means that the least well off in society have to invest more time and money into getting more education simply in order to keep up. Second, and perhaps more pernicious, is the possibility that egalitarian redistributions amplify inequality of opportunity. This is because as education becomes the dominant signal of a person's employability, the socioeconomic costs of not being highly educated rise significantly. Consequently, the pathways through which citizens can signal their ability and talent in order to improve their lot in life become restricted to formal academic education, an education that not everyone will or should desire for, let alone afford. As Caplan puts it:

You must dwell on the opportunities the poor have lost because of credential inflation. When most Americans didn't finish high school, dropouts faced little stigma in the job market. The stigma is now severe. When few Americans finished college, high school grads could plausibly work their way up the corporate ladder. No longer. (p. 214)

\section{Theorizing the Justice and Justification of Higher Education}

Even if signalling is not as significant an explanation for education's wage premium as Caplan thinks, there are still some important lessons to be learned in terms of how educational researchers should think about the relationship between political justice and educational institutions. Political philosophers and philosophers of education are by no means naïve about the non-ideal constraints that get in 
the way of policy recommendations based on arguments from moral and political principle (Moses, 2016). They understand that an ideally just education system will diverge from the one in which educators and policy-makers actually work. These "non-ideal conditions" are conceptualized as obstacles to political justice: discrimination, an unequal playing field, resource constraints (among other factors). That is to say, they undermine how we would ideally like educational opportunities to be fairly structured.

However, the signalling model discloses another category of non-ideality. Signalling is a good example of how the justness of an educational outcome also depends on the outcome being endogenous to the education process. That is to say, non-ideal conditions refer not only to social forces that get in the way of justice. They also include conditions that prevent opportunities from being actually educational-creditable to processes of teaching and learning, broadly conceived. In this respect, the possibility of signalling discloses something more troubling than inefficiency qua inefficiency, rather, it speaks to the possibility that one could have an education system that is perfectly just, but educationally vacuous. Consider: if the fundamental reason that higher education leads to an increase in the economic well-being of citizens is because it imparts skills that enable graduates to be more productive, securing equality of opportunity in higher education really is a question of educational justice. Graduates acquire real skills and undergo a substantive transformation, and they are rewarded for it. Higher education is a real educational opportunity. But if the reason why higher education leads to an increase in the economic well-being of citizens is, in the main, signalling, this means that higher education is mostly in the game of allocating opportunities to signal boost. It is not an educational opportunity. Consequently, higher education imposes an unfair burden on the public that funds it even if the opportunity to increase one's educational signal is structured justly. My point is that educational justice requires careful theorization about the conditions necessary for educational institutions to make a distinctive, and not merely a contingent or correlative, contribution to the values and aims it purports to advance.

\section{Political Philosophy and the Interpretation of Economic Arguments}

Caplan is intellectually forthright about his philosophical leanings - libertarianism generally, but more specifically Michael Huemer's philosophical anarchism. But he claims that his argument is freestanding from libertarianism or any other political philosophical tradition (p. 216). That is to say, the social science for signalling is strong enough that it justifies radical cuts even in the eyes of those who hold to philosophical traditions that are sympathetic to state-funded education.

I disagree. The data only compels us to conclude that a lot of the educational premium we think is due to a growth in the labour-relevant knowledge and skill of higher education graduates is filtering. If human capital justifies public funding for higher education, and the data shows that little in the way of human capital development is going on, we have reasons to cut, both in terms of the breadth of its curriculum and public funding.

However, the interpretation of what signalling means for the funding of higher education, including who should bear signalling's benefits and burdens, turns on what we think the value of higher education really ought to be for adult citizens in a free society. Cuts to public funding look like the only reasonable interpretation when we assume, as Caplan does, an educational universe where there is only one possible value: investing in our own human capital. ${ }^{5}$ And because he doesn't think this happens all that much, there's little to no justification for the system.

The fact that human capital is a weak justification for public funding for higher education could mean that there is no justification for higher education. But this seems a bit hasty. The weak case for human capital—assuming that it is a failure - opens the way for a fulsome consideration of other educational aims. In fact, one of these aims is not far removed from Caplan's preferred political philosophy. Across many variants of the liberal tradition, education is believed to be valuable for the role that it plays in helping children develop their internal capacity for individual liberty (i.e. positive liberty). It does this by exposing them to different options in life and ways of understanding the world that they would not have otherwise experienced. Let's imagine, for the sake of the argument, that education has similar value in adulthood. In this picture, education provides knowledge, understanding, and skills citizens need in order to participate in different social practices and ways of life of their choosing. These social forms and practices can include artistic, athletic, and other creative pursuits. They are only sometimes linked to employment. ${ }^{6}$

The liberal ideal of an education for individual freedom changes the significance of the signalling model for how we think about the justice and fairness of higher education. In a world where education ought to help citizens exercise their individual freedom, signalling "narrows" this aim by putting an incredible amount of socioeconomic pressure on a single social practice: employment. To be sure, some forms of employment really do require a higher education, but signalling leads to a scenario where nearly all employment requires a higher education. And when nearly all employment requires a higher education, it becomes hard to see how education could be valuable for anything else. 
Note that in this scenario, radical cuts to education will not solve the problem. Cutting funding won't help. The raw amount of public resources wasted on signalling would certainly go down, but it would not change citizen's main reason for flocking to higher education: the wage premium. The power of the signal would still crowd out the libertypromoting purpose of higher education. Cuts to the curriculum and a focus on vocations won't help, either. It would only compound the problem. This, because many of the fields, disciplines, and trades that we observe in modern higher education systems can be plausibly linked to a wide range of social practices and forms. To focus on the vocational would only serve to reinforce the problem: education signalling's narrowing effect.

Solving the signalling problem would require proposals that are quite different from Caplan's. If access to education over a life is key to the liberty of all citizens, and educational signalling undermines this purpose, our actions should be directed at scrambling the signal i.e. to make educational credentials a less reliable basis for statistical discrimination by employers. There are a number of ways to do this. First, with the exception of highly skilled professions where there is a direct relationship between what is taught and job performance (such as law, engineering, medicine, or the academic Phd) access should be non-selective, costless, and open to all regardless of academic merit. Second, attendance and participation should be the only necessary conditions for undergraduate degree completion. Show up to class, do the required work, and you can move on. If you don't do the work, your ability to participate in a desired social practice is impaired, which would defeat an individual's purpose in taking up that line of study. Third, if employers are using credentials to screen job applicants, and the public is subsidizing those credentials, employers should pay a signalling tax that increases the more credentialed the hire. ${ }^{6}$ Taken together, these reforms could work by undercutting the presumptions of ability and conformity that helps to make signalling pay off.

One might object that these policies would make education less lucrative. But this would be the point. For certain kinds of citizens, with certain professions in view, higher education would remain an important pathway to employment. But it would also free citizens to pursue education for different reasons, or not to pursue it at all, without the fear of severe economic punishment. One could argue that the proposed reforms are radical. They are. But they are no more radical than the proposals coming from the Caplan camp.

Finally, one could reject individual freedom as an aim of higher education. Reject away. My argument doesn't seek to justify the aim. My claim is that how we deal with signalling depends, importantly, on the educational value that we think that it undermines. If the data is right, signalling reveals the danger is an overreliance on the human capital version of this value. But rather than be disenchanted by this fact, it should prompt researchers to undertake a more serious investigation into what education in a free and open society ought to offer adult citizens. Then we can ask whether it justifies public funding of the level that higher education institutions currently enjoy in liberal democratic societies.

\footnotetext{
${ }^{1}$ And on the supply side, governments invest heavily in HE because of the assumed effects that it has on social returns.

${ }^{2}$ From a human capital perspective, it does not matter much what the particular educational aims are. As Arrow puts it, "[w]e can define 'skills' in strictly cognitive terms or to include non-cognitive habits and dispositions. It makes little difference from the standpoint of human capital theory because in either case education increases the productivity of graduates" (p. 194, 1973). ${ }^{3}$ One could argue that signalling has a very worthwhile social return: balancing the information asymmetry that employers face, which in turn helps to keep the labour market from failing (see Akerlof, 1978). However, employees can get just as much worker info with less education. If everyone was knocked down by one degree or credential, employers would still have the same quality of information. Caplan's (2018) fundamental worry is, as I see it, about how signalling has led society to a distorted sense of the value of education, not signalling itself: "Education is now the way the adult world measures the promise of youth. Scholastic failure doesn't merely reveal a lack of talent and drive; it signals deviance" (p. 288).

${ }^{4}$ Caplan (2018) uses the term "inequality of skill" (p. 213). But since egalitarians claim that equality means that individuals should be free to compete for valuable opportunities on the basis of talent as opposed to social advantage, we should take him to mean the same thing.

${ }^{5}$ Caplan concedes that a humanistic education is an alternative ideal. But he devotes an entire chapter trying to show that mass education has proven to be a total failure in realizing this ideal. However, by my lights his account of this ideal is a bit of a straw man. For example, he seems to think that a successful humanistic education involves the transmission of the propositional knowledge of particular fields or disciplines for the long term. If this is what a humanistic education involves, it would indeed be a failure. But see Hirst (1965) who puts the case for a broad liberal education on stronger conceptual footing.

${ }^{6}$ I offer a case for this way of thinking about the value of higher education in Martin (2016).

${ }^{7}$ What I am proposing here is "corrective taxation". Corrective taxes work to combat negative externalities.
} 


\section{References}

Akerlof, G. A. (1978). The market for "lemons": Quality uncertainty and the market mechanism. In P. Diamond \& M. Rothschild (Eds.), Uncertainty in economics (pp. 235-251). New York: Academic Press.

Arrow, K. J. (1973). Higher education as a filter. Journal of public economics, 2(3), 193-216.

Bou-Habib, P. (2010). Who should pay for higher education? Journal of Philosophy of Education, 44(4), 479-495.

Brighouse, H. (2004). Paying for higher education: Are top-up fees fair? Ethique et Economique, 2(1), 1-11.

Brighouse, H., \& Swift, A. (2006). Equality, priority, and positional goods. Ethics, 116(3), 471-497.

Caplan, B. (2018). The case against education: Why the education system is a waste of time and money. Princeton: Princeton University Press.

Eagan, K., Bara Stolzenberg, E., Bates, A. K., Aragon, M., Ramirez Suchard, M., \& Rios-Aguilar, C. (2016). The American freshman: National norms fall 2015. Los Angeles: UCLA Higher Education Research Institute.

Hirst, P. H. (1965). Liberal education and the nature of knowledge. Philosophical analysis and education, 2, 113-140.

Labaree, D. F. (2013, May). College: What is it good for? John Dewey Lecture presented at the annual meeting of the American Educational Research Association, San Francisco, CA.

Martin, C. (2016). Should students have to borrow? Autonomy, wellbeing and student debt. Journal of Philosophy of Education, 50(3), 351-370.

Morton, J. M. (2016). Unequal classrooms: Online higher education and non-cognitive skills. Philosophical Inquiry in Education, 23(2), 97-113.

Moses, M. S. (2015). Nonideal theory and philosophy of education: Considering what is while working toward what ought to be. Educational Theory, 65(2), 107-110.

\section{Recommended Citation}

Martin, C. (2019). The Case Against (Actually Existing) Higher Education: Human Capital, Educational Signalling, and Justice. On Education. Journal for Research and Debate, 2(6). https://doi.org/10.17899/on_ed.2019.6.4

About the Author

Christopher Martin is Associate Professor in the Faculty of Education and Associate Member of the Department of Economics, Philosophy and Political Science at The University of British Columbia. He is the author of Education in a Post-Metaphysical World (Bloomsbury Press, 2012), R.S. Peters (Bloomsbury Press, 2014; with Stefaan Cuypers), and Questioning the Classroom (Oxford University Press, 2016; with Dianne Gereluk, Bruce Maxwell, and Trevor Norris). His research areas include political philosophy and the philosophy of education. He is currently working on a book about the values and aims of higher education in liberal societies. 